\title{
Cytotoxicity evaluation and physicochemical properties of collagen isolated from silver carp tails as potential biomaterial
}

\author{
PETRUTA PREDA ${ }^{1,2} *$ ANA-MARIA ENCIU ${ }^{3,4}$, MARIOARA AVRAM ${ }^{1,5}$, \\ CRISTIANA TANASE ${ }^{3}$, MARIA DUDAU ${ }^{3,4}$, IULIANA MIHALACHE ${ }^{1,2}$, OANA \\ TUTUNARU $^{1,2}$, DIANA STAN ${ }^{5}$, ANTON FICAI ${ }^{2}$ \\ ${ }^{1}$ National Institute for Research and Development in Microtechnologies - IMT Bucharest, 126A Erou \\ Iancu Nicolae, 077190, Bucharest, Romania \\ ${ }^{2}$ Faculty of Applied Chemistry and Materials Science, Politehnica University of Bucharest, 1-7 Gh. \\ Polizu, 011061, Bucharest, Romania \\ ${ }^{3}$ Biochemistry-Proteomics Department, Victor Babes National Institute of Pathology, 99-101 Splaiul \\ Independenţei, 050096, Bucharest, Romania \\ ${ }^{4}$ Cell Biology and Histology Department, Carol Davila University of Medicine and Pharmacy, 8 Eroii \\ Sanitari, 050474, Bucharest, Romania \\ ${ }^{5}$ DDS Diagnostic SRL, 7 Vulcan County, 031427, Bucharest, Romania
}

\begin{abstract}
Collagen is widely used as a biomaterial in the pharmaceutical and cosmetic industries, in the production of hydrogels, wound dressings, bioactive nano/microfibers, controlled drug delivery systems, etc. The collagen isolated from the aquatic source has a higher biological activity and low risk of transmitting genetic diseases. In recent years the sustainable socio-economic and environmental principles promote the full use of natural resources. Thus, fish collagen extracted from fish by-products (skin, scales, bones and fins) can be valorized as a new collagen alternative source. In this work the enzymatic hydrolysis with pepsin of collagen isolation from silver carp (Hypophthalmichthys molitrix) tails fish has been investigated. We successfully isolated type I collagen with $90-95 \%$ purity as determined by FTIR, UV-Vis, EDX and SDS-PAGE analyses. The cytotoxicity of obtained collagen was evaluating by MTS assays.
\end{abstract}

Keywords Fish collagen, enzymatic hydrolysis, fish by-products, cytotoxicity.

To cite this article: PREDA P, ENCIU AM, AVRAM M, TANASE C, DUDAU M, MIHALACHE I, TUTUNARU O, STAN D, FICAI A. Cytotoxicity evaluation and physicochemical properties of collagen isolated from silver carp tails as potential biomaterial. Rom Biotechnol Lett. 2021; 26(4): 2808-2817. DOI: 10.25083/rbl/26.4/2808-2817

*Corresponding author: PETRUTA PREDA, National Institute for Research and Development in Microtechnologies - IMT Bucharest, 126A Erou Iancu Nicolae, 077190, Bucharest, Romania Politehnica University of Bucharest, Faculty of Applied Chemistry and Materials Science, 1-7 Gh. Polizu, 011061, Bucharest, Romania

E-mail: petruta.preda@imt.ro predapetruta04@gmail.com Phone: +40727 234312 


\section{Introduction}

The word "collagen" is derived from the "kolla" and "genos" greek words meaning glue and formation, respectively (MURALIDHARAN N \& al [1]). The collagen is the most abundant protein found in vertebrates and represents about $30 \%$ of the total body protein, which contributes significantly to the hardness of connective tissues such as dermis, bones, cartilage, tendons, ligaments and intima of blood vessels. Due to its biological, structural and homeostatic properties, the collagen is widely used in the biomedical and edible food packaging industry as well as in the food industry (VALENZUELAROJO DR \& al [2]).

Currently, XXIX types of collagen have been identified so far. According to their structure, these types were classified as fibrous, non-fibrous and micro-fibrous collagen. The type I collagen is the most abundant found in vertebrates (about $90 \%$ of the total collagen found in the body), and it is mainly present in skin, tendons, ligaments and bones. This type of collagen is widely used as a biomaterial in tissue engineering, cosmetics and pharmaceutical industry. Type I collagen is a triple helix protein, resulting from the interaction of tropocollagen monomers, consisting of two identical $\alpha 1$ and one $\alpha 2$ peptide chains. The peptides have approximately 1000 amino acids in length, with slight differences in their chemical composition. The molecular weight for these peptide chains is around $100 \mathrm{kDa}$. The collagen molecule is characterized by two repetitive glycine-proline- $\mathrm{X}$ and glycine- $\mathrm{X}$ hydroxyproline amino acid sequences, where $\mathrm{X}$ can be any other amino acids. Glycine and hydroxyproline are very important in the structure and stability of collagen (VALENZUELA-ROJO DR \& al [2]).

Special attention was recently directed towards collagen isolated from aquatic sources (eg. fish, jellyfish, sponges, shark etc.) because this collagen has a low risk of transmitting genetic diseases when compared to collagen isolated from terrestrial sources (eg. cattle, rats, pigs and chickens). Moreover, sustainable socio-economic and environmental principles promote the full use of natural resources, including the idea of revalorized of fins, bones, skin and scales fish by-products. Therefore, these by-products resulting from the fish processing industry can offer alternative sources for collagen production (MAHBOOB S \& al [3]; PRASHANT KB \& al [4]; SANCHEZ A \& al [5]). Fish collagen showed better solubility in water, lower viscosity and degradation at low temperature (VALENZUELA-ROJO DR \& al [2]), higher biological activity and lower content in proline and hydroxyproline (MURALIDHARAN N \& al [1]) as compared to mammalian collagen.

The yield of collagen isolated from fish waste depends on species, waste type, age, sex and fish body weight. The extraction yield of collagen can be in the range of $10-30 \%$ in the case of cattle, pigs and sheep (as raw materials), 5-6\% in the case of birds and varies between $5 \%$ to $80 \%$ for fish by-products such as skin and fins, depending on the raw material (SCHMIDT MM \& al [6]). It should be noted that the extraction yields also depends on the used extraction method. In practice, the collagen can be obtained by acidic or enzymatic hydrolysis. The latter is preferred due to reduction of processing time as well as the increase of the extraction yield (MAHBOOB \& al [3]); SCHMIDT MM\& al [6]; DUAN R \& al [7]; WIBAWA SF \& al [8]; WU J \& al [9]). For example, Rodziewicz-Motowidło et al (2008) demonstrated that the silver carp skin wastes are rich sources of type I collagen. The authors reported a 75\% yield of type I collagen, following acid hydrolysis, by using the extraction with $0.5 \%$ glycolic acid (RODZIEWICZ-MOTOWIDŁO S \& al [10]). Other researchers have reported obtaining of type I collagen from scale of silver carp with an extraction yield of $0.86 \%$ and $2.32 \%$ by acid hydrolysis and enzymatic hydrolysis, respectively (ZHANG JJ \& al [11]). Also, Zhang et al, (2009) reported the purification of type I collagen from silver carp skin collagen with an extraction yield of $65 \%$ by using the acid hydrolysis (ZHANG $\mathbf{J}$ $\&$ al [12])

The collagen isolated from aquatic source is a biomaterial which has a wide range of applications in the biomedical industry (cosmetics, pharmaceuticals and medical devices) as well as in the food industry (LIM YS \& al [13]). Regarding the Romanian market, the most frequently processed fish species are carp, amur and silver carp which represent about $85 \%$ of the local fish production originates from aquaculture and rivers, followed by perch, pike and trout (about 15\% from local aquacultures and rivers) and last, the marine fish (salmon, herring, sprat and mackerel) (Overview of the Romanian fisheries and aquaculture sector, https://www.eurofish.dk/romania [14]). To monetize fish by-products resulted from Romanian fishing industry, we have proposed to isolate collagen from silver carp (Hypophthalmichthys molitrix) tails for further exploitation in biomedical industry. We demonstrated here that the silver carp tails could be also included as a potential collagen source instead to be discard as waste. So far, to our knowledge, this type of fish by-products has not been studied as a potential source of collagen.

\section{Materials and Methods}

\section{Materials}

The chemical agents used in this research were purchased, as follows: sodium chloride $(\mathrm{NaCl})$ (purity $\geq 99.5 \%$, Honeywell-Fluka, Germany), sodium hydroxide $(\mathrm{NaOH})$ (granulated, purity $\geq 97 \%$, EMPLURA®, Germany), ethylenediaminetetraacetic acid (EDTA) (SigmaAldrich, BioUltra, purity $\geq 99 \%$, Germany), and pepsin (conc. > 400U/mg, Sigma Aldrich, 
Germany). The dialysis bags with MWCO (Molecular Weight Cut-Off) of $12 \mathrm{kDa}$ were purchased from (SigmaAldrich, USA). Acetic acid $\left(\mathrm{CH}_{3}-\mathrm{COOH}\right)$ (Chimreactiv, Romania) and ethanol $\left(\mathrm{C}_{2} \mathrm{H}_{5} \mathrm{OH}\right)(96 \%$, Chimreactiv, Romania). The silver carp tails (from fish fishing from Danube river) were procured from a local fish market. Commercial type I collagen from bovine tendon (Advanced BioMatrix, USA) was used as reference (coded M).

\section{The fish collagen extraction method}

The extraction of collagen, in triplicate, was performed by pepsin digestion activated in acetic acid medium. This method was adapted in accordance to other papers (SCHMIDT MM \& al [6]; LI D \& al [15]; BERILLIS P \& al [16]; MAHBOOB S \& al [17]; BHAGWAT PK \& DANDGE PB [18]); BLANCO M \& al [19]). The isolation process had three stages: demineralization, enzymatic hydrolysis and purification. In the first stage, the fish tails waste were shredded to about $1 \times 1 \mathrm{~cm}^{2}$ and washed very well with cold deionized water about 10 times, further they were kept at $4-6^{\circ} \mathrm{C}$ for $24 \mathrm{~h}$ in $10 \%$ ethanol in a ratio of 1:5 (weight:volume) for the fat removal. After that, the raw material was washed with deionized water (five times) and $0.8 \mathrm{M} \mathrm{NaCl}$ (three times) in order to remove the impurities. Afterwards, the salt was removed by washing with deionized water (three times). Also, the non- collagen proteins were removed with a mixture of $1 \mathrm{M} \mathrm{NaCl}$, $0.1 \mathrm{M} \mathrm{NaOH}$ and $20 \mathrm{mM}$ EDTA at a $\mathrm{pH}$ of 7.5 for $72 \mathrm{~h}$, in ratio of 1:5 (weight:volume), at $4-6^{\circ} \mathrm{C}$. Subsequently, a new rinsing with deionized water was applied and the demineralization process was performed by treating of the waste with $0.3 \mathrm{M}$ EDTA at a $\mathrm{pH}$ of 7.4 for $48 \mathrm{~h}$ at a temperature in the range of 4 to $6^{\circ} \mathrm{C}$. The enzymatic hydrolysis of collagen was conducted in acidic conditions with pepsin $800 \mathrm{U} / g$ and $1200 \mathrm{U} / g$, respectively. The enzymatic process was performed in $0.5 \mathrm{M}$ acetic acid, in a ratio of 1:5 (weight: volume), at $4-6^{\circ} \mathrm{C}$ for $24 \mathrm{~h}$. After pepsin digestion, the impurities were removed from the extracted solution by filtration through gauze and centrifugation at $9,000 \mathrm{rpm}$ for 15 minutes at a temperature $<20^{\circ} \mathrm{C}$. The final supernatant was kept with $2 \mathrm{M} \mathrm{NaCl}$ for $24 \mathrm{~h}$ at $4-6^{\circ} \mathrm{C}$ for the collagen precipitation. The precipitated collagen was filtered through filter paper. Collagen purification was performed by solubilization of precipitated collagen in $0.5 \mathrm{M}$ acetic acid. It was then loaded into dialysis bags and dialyzed in the presence of deionized water for $20 \mathrm{~h}$ at a temperature $<20^{\circ} \mathrm{C}$ under stirring (400 rpm). The dialyzed samples were frozen and lyophilized. The lyophilized collagen in the form of sponges was stored in the refrigerator. The percentage of collagen yield was calculated using equation (1) (ARDHANI FAK \& al [20]).

$$
\text { Fish collagen } \%=\frac{\text { mass of collagen lyophilized }(g)}{\text { mass of fish tails }(80 \mathrm{~g})} \times 100
$$

\section{Fourier Transform Infrared Spectroscopy (FTIR) analysis}

In order to highlight the specific functional groups, the type of collagen and qualitative verification of the purity, the FT-IR analysis was performed. The isolated collagen and the reference (commercial type I collagen) were analyzed in ATR mode by using a diamond crystal, at room temperature. The spectra were recorded at wavenumbers between 4000 and $400 \mathrm{~cm}^{-1}$, at a resolution of $4 \mathrm{~cm}^{-1}$, using an infrared spectrophotometer Bruker Optics Tensor 27 (Opus software).

\section{UV-Visible Spectroscopy analysis}

The UV-visible (UV-Vis) spectrum of collagen isolated from the silver carp tails was measured by using the Hitachi U-0080D spectrophotometer. The lyophilized collagen was solubilized in deionized water by centrifugation at $9000 \mathrm{rpm} / 15 \mathrm{~min}$ and a temperature $<20^{\circ} \mathrm{C}$. The absorbance of the collagen samples was measured in the wavelength range of 190 to $400 \mathrm{~nm}$.

\section{Energy-dispersive X-ray spectroscopy (EDX) analysis}

Elemental analysis was performed to evaluate the purity of the fish collagen after the extraction process. The elemental composition of the isolated fish collagen as well as the reference were analyzing by Energy-dispersive
X-ray spectroscopy (EDX) using a Field emission scanning electron microscopy (FE-SEM) Nova NanoSEM 630 (FEI Company, USA), equipped with EDX detector (EDAX TEAM TM, USA). EDX spectra were collected at an acceleration potential of $15 \mathrm{kV}$ and a working distance of $5 \mathrm{~mm}$.

\section{SDS-PAGE electrophoresis}

The collagen from silver carp tails was solubilized in $0.1 \mathrm{M}$ acetic acid to a concentration of $5 \mathrm{mg} / \mathrm{mL}$. $20 \mu \mathrm{g}$ of collagen samples were denaturated in Laemmli $2 \mathrm{x}(1: 1$ volume), then loaded onto a $10 \%$ polyacrylamide mini-gel and migrated for $2 \mathrm{~h}$ at $40 \mathrm{~mA}$. After electrophoresis, the gel was incubated in a fixing solution (methanol 40\%: acetic acid $10 \%$ ) for $30 \mathrm{~min}$, stained by $0.1 \%$ Coomassie brilliant blue for $30 \mathrm{~min}$, then de-stained with $10 \%$ acetic acid until the desired background. The molecular weight was estimated by reference to a high molecular weight marker (HiMark Prestained High Molecular Weight Protein Standard, ThermoFisher, USA).

\section{Cytotoxicity assays}

\section{Cell culture}

3T3NIH fibroblasts were routinely cultured in DMEM/F12 cell culture medium (Gibco) supplemented with $10 \%$ fetal bovine serum (Corning) and $1 \%$ antibioticantimycotic (Sigma-Aldrich) in a humidified $5 \% \mathrm{CO}_{2}$ 
atmosphere, at $37^{\circ} \mathrm{C}$. For proliferation assays the cells were trypsinized, counted and seeded on 96 well plates at the desired density.

\section{Cell viability}

The cytotoxicity was evaluated by cell viability assessed for $3 \mathrm{~T} 3 \mathrm{NIH}$ fibroblasts in the presence of the collagen samples. Cell viability was assessed based on the reduction of a stabilized tetrazolium compound by viable cells. 10000 cells were seeded in triplicates o/n (overnight) in 96-well plates and incubated the next day with cell culture medium and/or serial dilutions of collagen stock solution for additional $24 \mathrm{~h}$ to $48 \mathrm{~h}$. A positive control (non-treated cells) was included. Additional triplicates of cell-free wells were incubated with tested solutions, for background subtraction. In the day of the reading, the cell media was removed and $100 \mu \mathrm{L}$ of fresh medium and $20 \mu \mathrm{L}$ of 3-(4,5-dimethylthiazol-2-yl)-5-(3-carboxymethoxyphenyl)2-(4-sulfofenyl)-2H-tetrazolium (MTS) reagent (CellTiter 96® AQueous One Solution Reagent, Promega, USA) were added to each well. The plate was incubated at $37^{\circ} \mathrm{C}$ for $3 \mathrm{~h}$ in a humidified, $5 \% \mathrm{CO}_{2}$ atmosphere. The absorbance of colored solution was read at $490 \mathrm{~nm}$ by using a microplate reader Anthos Zenyth 3100 (Austria). Cell viability was assessed in according with the equation (2).

$$
\text { Cell viability }(\%)=\frac{\text { sample } O D-\text { background } O D}{\text { average control } O D-\text { average control background } O D} \times 100
$$

\section{Results and Discussion}

\section{Extraction of collagen from $H$. molitrix tails}

The most commonly used fish by-product is the skin for the collagen extraction, where the highest amount of collagen is found and no additional demineralization process is required, followed by fins, bones and scales (MAHBOOB S \& al [3]; SCHMIDT MM \& al [6]; DUAN R \& al [7]); WIBAWA SF \& al [8]; WU J \& al [9]; PANG S \& al [21]). The fish by-product selected in this paper for the collagen production is represented by the silver carp (Hypophthalmichthys molitrix) tails, a source which is, by our knowledge, the first time reported in the literature. In order to produce collagen, $80 \mathrm{~g}$ of silver carp tails were processed by the enzymatic digestion with pepsin in two different concentrations, $800 \mathrm{U} / \mathrm{g}$ and $1200 \mathrm{U} / \mathrm{g}$, respectively. The isolation of silver carp tails collagen was performed in two successive extractions for each pepsin concentration.

Digestion with $800 \mathrm{U} / \mathrm{g}$ yielded to $0.27 \%$ collagen, whereas in the case of digestion with $1200 \mathrm{U} / \mathrm{g}$, it increased twice, $0.55 \%$. Therefore, the hydrolysis with $1200 \mathrm{U} / \mathrm{g}$ pepsin was more efficiently. Hence, the fish collagen output depended on the pepsin concentration. Overall, from $80 \mathrm{~g}$ of raw material, $221 \mathrm{mg}$ of silver carp tails collagen were obtained by the enzymatic digestion using a low catalytic pepsin activity and $440 \mathrm{mg}$ in the case of high catalytic pepsin activity. So far, no other papers of fish tails processing were reported in the literature to set a standard for future references. Yu et al (2018) showed that the extraction yield of Nibea japonica skin collagen significantly increased from $66.35 \%$ to $79.93 \%$ when pepsin concentration varied from 800 to $1200 \mathrm{U} / \mathrm{g}$ (YU F $\&$ al [22]). It should be noted that the percentage of collagen extracted from the raw materials can vary from batch to batch, as well as age, sex and body weight (SCHMIDT MM \& al [6]).

\section{Fourier Transform Infrared Spectroscopy (FTIR) analysis}

The FTIR spectra of collagen samples are shown in Figure 1. The IR spectra of isolated fish collagen and reference collagen indicated the presence of the five characteristic spectral bands, such as amide A, amide B and amides I, II and III. These bands are present in all analyzed samples.

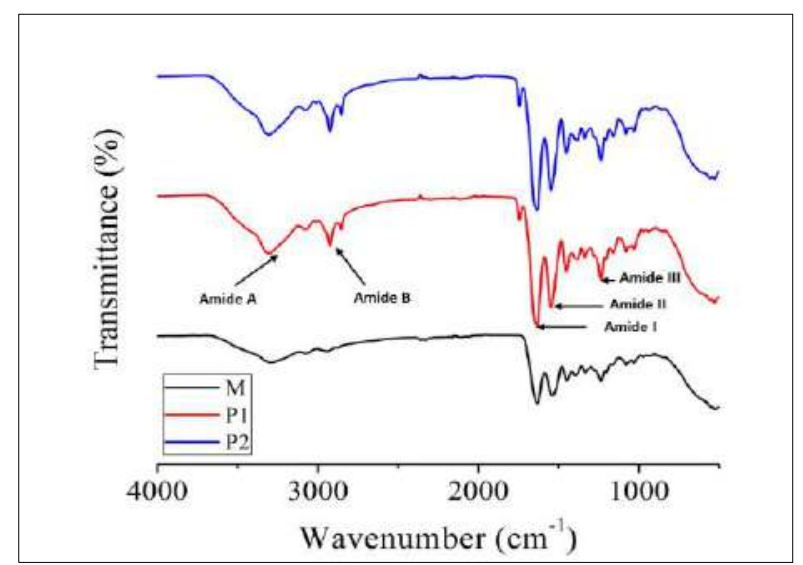

Figure 1. FTIR spectra of lyophilized collagen. P1-collagen isolated with $800 \mathrm{U} / \mathrm{g}$ pepsin; P2- collagen isolated with $1200 \mathrm{U} / g$ pepsin; M-commercial type I collagen. 
The vibration band in the $3300 \mathrm{~cm}^{-1}$ region is assigned to the amide A structure, and the band measured in the $2950 \mathrm{~cm}^{-1}$ region is assigned to the amide $B$. Regarding amides I and II, their vibration bands are located at $1645 \mathrm{~cm}^{-1}$ and $1540 \mathrm{~cm}^{-1}$, respectively. Such vibration bands are caused by the $\mathrm{N}-\mathrm{H}$ bending vibration coupled with a $\mathrm{C}-\mathrm{N}$ stretching vibration and they normally occur in the $1550-1600 \mathrm{~cm}^{-1}$ region, thus the recorded shift to lower wavenumbers suggests the existence of hydrogen bonds and the interhelical bonds (DUAN R \& al [7]); AHMAD M \& al [23]); MING-MAO C \& al [24]). Finally, the amide III band was recorded at $\sim 1240 \mathrm{~cm}^{-1}$, which confirms the un-denatured extraction of collagen and the triple helix structure of collagen. Similar records have been reported for type I collagen from fish byproducts (WU J \& al [9]; ALVES AL \& al [25]); TANG Y $\&$ al [26]; CHINH NT \& al [27]). Moreover, the triple helix structure of the isolated collagen samples is confirmed by comparing the FTIR spectra of isolated collagen from silver carp tails with the spectrum of commercial type I collagen, when the IR spectra show similar bands in the region stated above. Therefore, the FT-IR analysis confirms that our isolated compound is type I collagen.

\section{UV-visible Spectroscopy analysis}

The UV-Vis spectra of the isolated collagen samples were recorded and show the characteristic absorption peak centered at $197 \mathrm{~nm}$ wavelength (Figure 2). The collagen was solubilized in water. In agreement with the electronic absorption profiles characteristic to the proteins/amino acids in aqueous medium, they have a wide range absorption in the UV-visible region (185$320 \mathrm{~nm}$ ) of the electromagnetic spectrum (SAUMYA P $\&$ al [28]). Therefore, the absorption spectra of tested samples confirm their protein nature and the existence of amino acids as a strong indicative of the presence of the collagen protein.

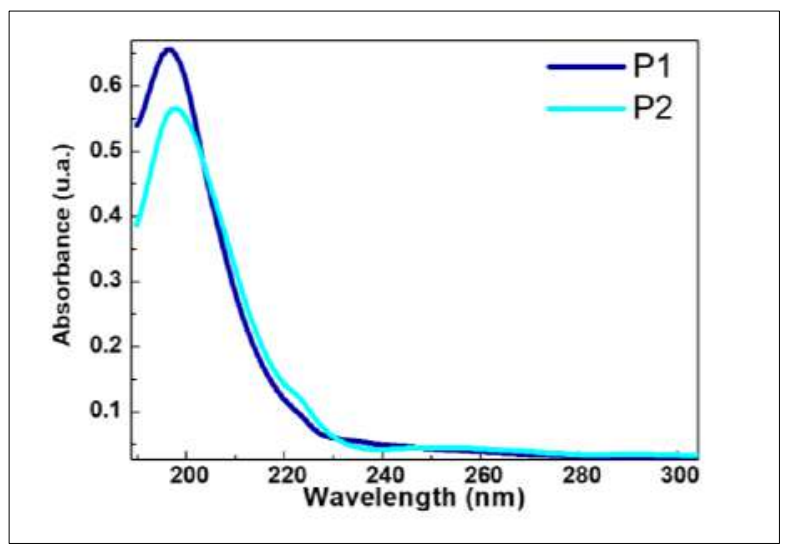

Figure 2. UV-visible spectroscopy of collagen from silver carp tails. P1 - collagen isolated with $800 \mathrm{U} / g$ pepsin; P2- collagen isolated with $1200 \mathrm{U} / \mathrm{g}$ pepsin.

Chinh et al (2019) reported an absorption peak at $192.07 \mathrm{~nm}$ characteristic to the absorption of type I collagen extracted from carp scales of genus Cyprinus (CHINH NT \& al [27]). Also, Na (1988) investigated the absorption of type I collagen extracted from calf skin by $\mathrm{UV}-\mathrm{V}$ is analysis and found a peak centered at $199 \mathrm{~nm}$ (NA GN \& al [29]).

Tyrosine and tryptophan usually show absorptions in the wavelength range of 280-300 nm. These amino acids are found in small amounts in the collagen molecule (KITTIPHATTANABAWON P \& al [30]), so the appearance of these peaks is not possible in collagen samples. Hence, the appearance of these peaks at 280-300 nm suggested the existence of other proteins in the analyzed sample due to the insufficient purification of collagen. Therefore, the existence in the UV-vis spectrum of a single peak recorded at $197 \mathrm{~nm}$ suggests the obtaining of a pure structure in the case of obtained collagen.

\section{Energy-dispersive X-ray spectroscopy (EDX) analysis}

The elemental analysis of all collagen samples was performed by the EDX technique and the following elements were identified $\mathrm{C}, \mathrm{N}, \mathrm{O}, \mathrm{S}, \mathrm{Cl}, \mathrm{Ca}, \mathrm{Al}$, and $\mathrm{Na}$. The spectra for some representative samples are shown in Figure 3, and the elements recorded for all triplicate extraction are shown in Table 1.

The presence of sodium and chlorine in a percentage of about $10 \%$ (Table 1) was recorded in the case of two isolated collagen sample (isolated collagen by hydrolysis with $800 \mathrm{U} / \mathrm{g}$ and $1200 \mathrm{U} / \mathrm{g}$ pepsin contents, respectively) is due to a poor dialysis, which is the result of higher amount of collagen solubilized in acetic acid. The higher concentration of collagen in the solution made the dialysis process more difficult, due to the high viscosity of the solution. However, it should be noted that for the other samples after $20 \mathrm{~h}$ of dialysis with deionized water 

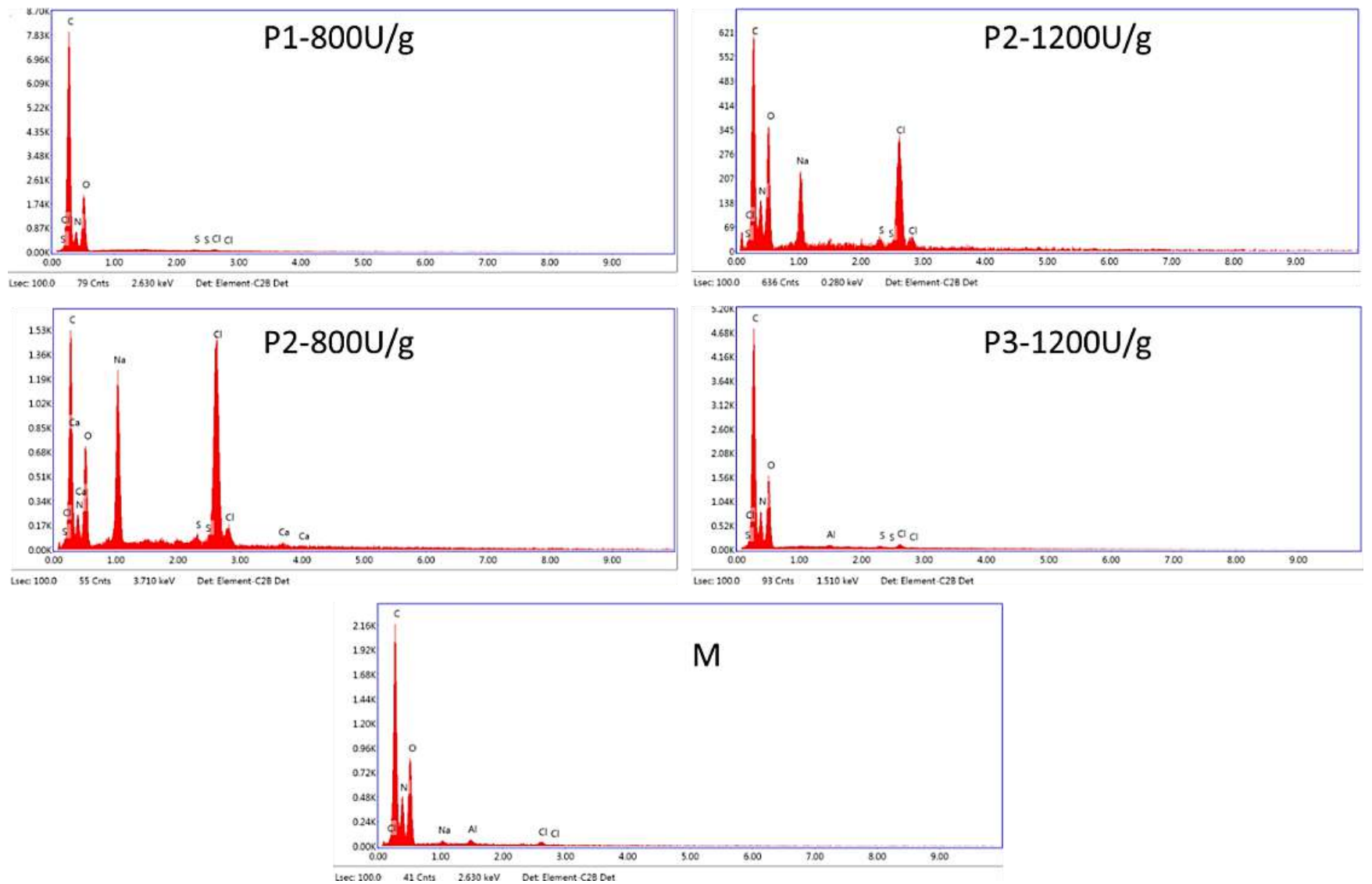

Figure 3. EDX spectrum for collagen. P1 and P2- fish collagen isolated with 800U/g pepsin, in accordance to Table1; P2 and P3- fish collagen isolated with 1200U/g pepsin, in accordance to Table1; M- commercial type I collagen (from tendon bovine), in accordance to Table 1.

Table 1. Percentage of element identified by EDX analysis in fish collagen samples

\begin{tabular}{|c|c|c|c|c|c|c|c|c|c|}
\hline \multirow[t]{2}{*}{ Sample } & \multicolumn{8}{|c|}{ The element/ mass percent (\%) } & \multirow{2}{*}{$\begin{array}{c}\text { Purity } \\
(\%)\end{array}$} \\
\hline & $\mathbf{C}$ & $\mathbf{N}$ & $\mathbf{O}$ & $\mathbf{S}$ & $\mathbf{C l}$ & $\mathbf{C a}$ & Al & $\mathbf{N a}$ & \\
\hline $\mathrm{P} 1-800 \mathrm{U} / \mathrm{g}$ & 47.63 & 19.02 & 32.69 & 0.27 & 0.39 & - & - & - & 99.61 \\
\hline $\mathrm{P} 2-800 \mathrm{U} / \mathrm{g}$ & 41.87 & 10.87 & 16.82 & 0.50 & 17.69 & 0.45 & - & 11.8 & 70.06 \\
\hline $\mathrm{P} 3-800 \mathrm{U} / \mathrm{g}$ & 44.68 & 21.84 & 31.17 & 0.73 & 1.57 & - & - & - & 98.42 \\
\hline P1-1200U/g & 42.38 & 23.40 & 32.54 & 0.65 & 1.03 & - & - & - & 98.97 \\
\hline $\mathrm{P} 2-1200 \mathrm{U} / \mathrm{g}$ & 45.36 & 10.62 & 22.89 & 0.40 & 13.02 & - & - & 7.71 & 79.27 \\
\hline P3-1200U/g & 40.81 & 24.36 & 33.55 & 0.31 & 0.80 & - & 0.18 & - & 99.02 \\
\hline $\mathrm{M}$ (reference) & 42.52 & 19.42 & 35.80 & - & 0.74 & - & 0.74 & 0.78 & 97.74 \\
\hline
\end{tabular}

a significant elimination of the sodium and chlorine was obtained. Similar, Chinh et al (2019) demonstrated that after $48 \mathrm{~h}$ of dialysis with distilled water, the sodium and chlorine are completely eliminated from the collagen isolated from carp scales (CHINH NT \& al [27]). Moreover, the results obtained by the EDX analysis provided information on the demineralization process. The absence of the calcium in the most studied replicas suggested that the demineralization process of waste went very well at $0.3 \mathrm{M}$ EDTA. The most important property of EDTA is its ability to chelate the metal ions to form a metal: EDTA complex of $1: 1$ ratio (WANG Y \& REGENSTEIN JM \& al [31]). Pati et al (2010) confirmed by TGA analysis the good demineralization with $0.5 \mathrm{M}$ solution of EDTA for $48 \mathrm{~h}$ for Rohu and Catla scales waste, the residue of mineral in the isolated collagen being $0.9 \%$ (PATI F \& al [32]).

Wang and Regenstein (2009) proved that by using a 0.2 M EDTA, the calcium salt was best removed from silver carp scales with decalcification $>90 \%$ (WANG Y 
\& REGENSTEIN JM \& al [31]). Sionkowska and Kozłowska (2014) confirmed by EDX analysis that the demineralization was almost completed after $48 \mathrm{~h}$ of $0.5 \mathrm{M}$ EDTA treatment for the Esox lucius scales (SIONKOWSKA A \& KOZŁOWSKA J [33]).

Also, the presence of sulfur proved by EDX could provide information on the existence of cysteine and/or methionine in the structure of the silver carp tails collagen. The methionine and cysteine amino acids have been reported in small amounts in the structure of type I collagen extracted from various fish species. Methionine has been reported in structure of the type I collagen in variable concentrations, such as $9 \%$ methionine content in Catla catla scales collagen (PATI F \& al [32]), 10\% methionine content in Nibea japonica skin collagen (TANG Y \& al [26]), $0.59 \%$ methionine content in Neoceratodus skin collagen (ZHANG J \& al [12]). Cysteine has not been reported in these studies. Chen et al (2019) reported $18.5 \%$ methionine content and $0.57 \%$ cysteine content in type I collagen isolated from $T$. flavidus skin waste (CHEN J \& al [34]). Mahboob et al (2014) has isolated collagen from silver carp (Hypophthalmichthys molitrix) skin, scales and fins and had a methionine content of $14 \%, 12 \%$ and $15 \%$, respectively, but no cysteine was present (MAHBOOB S $\&$ al [3]). Also, Wu et al (2019) reported $14 \%$ methionine in silver carp scales collagen (WU J \& al [9]).
In accordance with the quality certificate, the reference collagen used here has a purity to high than $96 \%$, which has been demonstrated by the EDX analysis (97.74\% purity). When compared to the reference collagen, it was observed that for most tested replicates of fish tails collagen, the purity percentage was higher than $98 \%$ (the purity percentage was calculated as the sum of the mass percent (\%) of the $\mathrm{C}, \mathrm{N}, \mathrm{O}$ and $\mathrm{S}$ elements). Hence, we can say that our silver carp tails collagen can be a commercially- graded pure collagen.

\section{SDS-PAGE electrophoresis}

In order to estimate the type of the collagen isolated from the silver carp tails, we performed SDS-PAGE electrophoresis (Sodium Dodecyl Sulfate-PolyAcrylamide Gel Electrophoresis) for several samples of obtained collagen (lanes 3 and 4) and compared them to reference type I collagen from bovine tendon (lane 2) (Figure 4). All collagen samples were reconstituted as recommended for the reference collagen, in 0.1 M acetic acid. Samples of isolated collagen showed prominent bands specific for $\alpha(\alpha 1$ and $\alpha 2)$ and $\beta$ chains and recorded at a molecular weight similar with that of reference collagen (type I collagen).

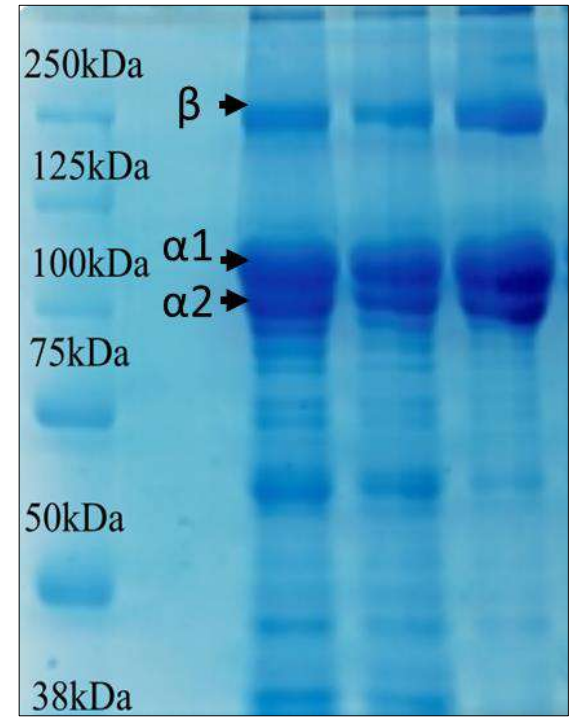

Figure 4. SDS-PAGE electrophoresis: lane 1 - High molecular weight marker (HiMark Prestained High Molecular Weight Protein Standard, ThermoFisher); lane 2 - reference commercially collagen; lane 3 isolated collagen with pepsin digestion $(800 \mathrm{U} / \mathrm{g})$; lane 4 - isolated collagen with pepsin digestion $(1200 \mathrm{U} / \mathrm{g})$.

The density of band recorded at $115 \mathrm{kDa}$ attributed to $\alpha 1$ chain was higher than the $\alpha 2$ chain recorded at $100 \mathrm{kDa}$. The presence of these chains in this ratio is specific for type I collagen. A similar result was reported for the fish type I collagen in another studies (MURALIDHARAN N \& al [1]; PRASHANT KB \&
DANDGE PB \& al [4]; (ZHANG JJ \& al [11]; PANG S \& al [21]; YU F \& al [22]; TANG Y \& al [26]).

The presence of $\beta$ chain (dimer) at molecular weight of $250 \mathrm{kDa}$ means that the samples show inter- and intra-molecular cross-links of collagen subunits (ZHANG $\mathrm{J} \&$ al [12]; LIM YS \& al [13]). The $\alpha 1, \alpha 2$ and $\beta$ chains 
observed for isolated collagen with 1200 and $800 \mathrm{U} / \mathrm{g}$ pepsin at similar molecular weight with the reference type I collagen, suggest that the type I collagen was obtained and, the used conditions do not alter the peptides length.

\section{Cytotoxicity assays}

The cytotoxicity was determined using MTS method. The MTS assay was used to assess the NIH-3T3 fibroblasts compatibility with the collagen and results are shown in Figure 5. NIH-3T3 fibroblasts were incubated for $24 \mathrm{~h}$ and $48 \mathrm{~h}$ with various dilutions from initial collagen solution $(5 \mathrm{mg} / \mathrm{mL})$ up to a concentration regularly used in cell biology research protocols $(\mu \mathrm{g} / \mathrm{mL})$ (SOMAIAH C \& al [35]), where collagen is used as coating/substrate protein.

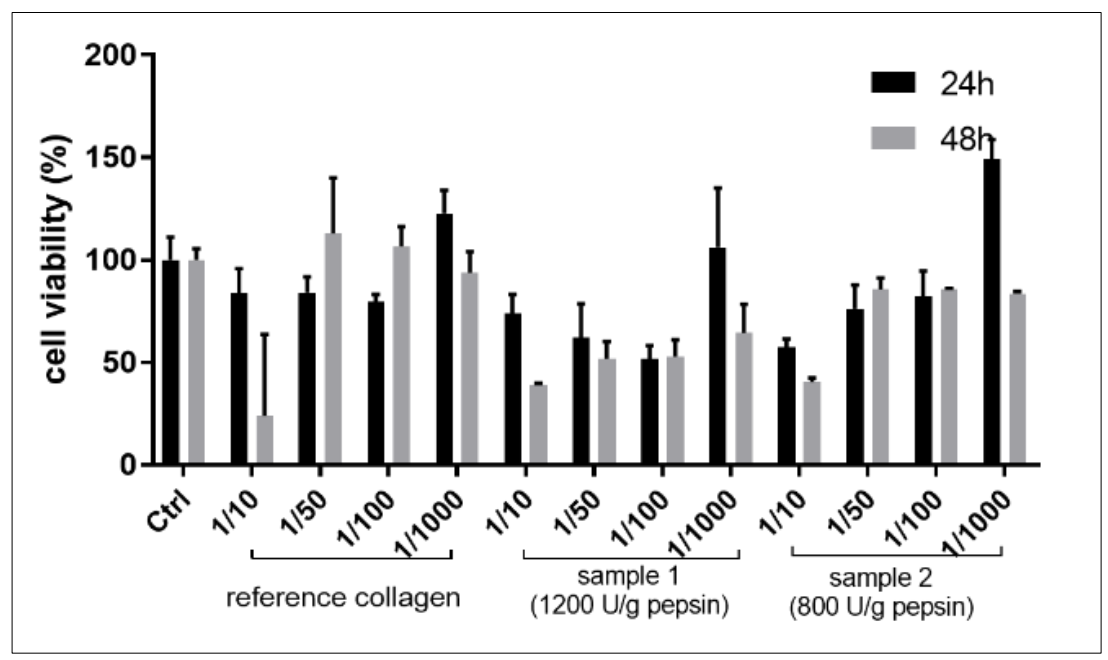

Figure 5. The NIH-3T3 fibroblasts treated with the collagen samples for cytotoxicity assays. ctrl- untreated cells with collagen; reference collagen - type I collagen from bovine tendon; sample 1- collagen isolated with $1200 \mathrm{U} / \mathrm{g}$ pepsin; sample 2- collagen isolated with $800 \mathrm{U} / \mathrm{g}$ pepsin; $( \pm \mathrm{SD}, \mathrm{n}=3)$.

The results showed for both $24 \mathrm{~h}$ and $48 \mathrm{~h}$ periods that the cell viability of NIH-3T3 fibroblasts is over $50 \%$ at concentrations lower than $100 \mu \mathrm{g} / \mathrm{mL}$ (1/50 dil) for isolated collagen which confirms non-cytotoxic activity. Also, for all concentrations of fish collagen, both isolated collagen samples and collagen reference a slight decrease in cell viability at $48 \mathrm{~h}$ was recorded, so cell proliferation showed a concentration and time-dependent effect of tested collagen species. Moreover, it can be seen at $24 \mathrm{~h}$ that all collagen samples at a concentration of $5 \mu \mathrm{g} / \mathrm{mL}$ (1/1000 dil) promote cell proliferation when we refer to the untreated cells.

\section{Conclusions}

Experimental results confirm the isolation of type I collagen from silver carp tails by enzymatic hydrolysis using pepsin. The highest amount of collagen was isolated when using the concentration of $1200 \mathrm{U} / \mathrm{g}$ pepsin. FTIR analysis confirmed the triple helix structure of the undenaturated type I collagen as well as its high purity. Moreover, UV-Vis and EDX analyses confirm that the lyophilized collagen is pure. SDS-PAGE analysis, also revealed the purity and the un-denaturated structure of the obtained type I collagen of fish waste origin. The silver carp tails could be used as a new source of non-cytotoxic collagen and could be further used as biomaterial. Further work is needed to increase the efficiency of the extraction process including better cut of the raw material, faster and more repetitive extractions from the raw material by optimizing the extraction parameters.

\section{Conflicts of Interest}

The authors declare that there are no conflicts of interest.

\section{Acknowledgements}

This work was partially supported by grant COP A 1.2.3., ID: P_40_197/2016, Ctr 925 and by the grant P_40_283, SMIS code 105623, Ctr. 77/2016/1C. The work of PETRUTA PREDA has been funded by the Operational Programme Human Capital of the Ministry of European Funds through the Financial Agreement 51668/09.07. 2019, SMIS code 124705. 


\section{References}

1. N. MURALIDHARAN, R.J. SHAKILA, D. SUKUMAR, G. JEYASEKARAN. Skin, bone and muscle collagen extraction from the trash fish, leather jacket (Odonus niger) and their characterization. J Food Sci Technol, 50, 1106-1113 (2013).

2. D.R. VALENZUELA-ROJO, J. LÓPEZ-CERVANTES, D.I. SÁNCHEZ-MACHADO. Tilapia (Oreochromis aureus) collagen for medical biomaterials, http://dx.doi.org/10.5772/intechopen.77051, (2018).

3. S. MAHBOOB, S. HAIDER, S. SULTANA, K.A. AL-GHANIM, AL-MISNED F., H.F. AL-KAHEM, A. BALAW I, AHMAD Z. Isolation and characterisation of collagen from the waste material of two important freshwater fish species. J. Anim. Plant Sci., 24, 1802-1810 (2014).

4. K.B. PRASHANT, P.B. DANDGE. Isolation, characterization and valorizable applications of fish scale collagen in food and agriculture industries. Biocatal. Agric. Biotechnol., 7, 234-240 (2016).

5. A. SANCHEZ, M. BLANCO, B. CORREA, R.I. PEREZ-MARTIN, C.G. SOTELO. Effect of fish collagen hydrolysates on type I collagen mRNA levels of human dermal fibroblast culture. Mar. Drugs, 16(5), doi: 10.3390/md16050144 (2018).

6. M.M. SCHMIDT, R.C.P. DORNELLES, R.O. MELLO, E.H. KUBOTA, M.A., MAZUTTI, A.P. KEMPKA, I.M. DEMIATE. Collagen extraction process. Int. Food Res. J. 23(3), 913-922 (2016).

7. R. DUAN, J. ZHANG, X. DU, X. YAO, K. KONNO. Properties of collagen from skin, scale and bone of carp (Cyprinus carpio). Food Chem., 112, 702-706 (2009)

8. S.F. WIBAWA, D.S. RETNONINGRUM, M.T. SUHARTONO. Acid soluble collagen from skin of common carp (Cyprinus carpio L), red snapper (Lutjanus sp.) and milkfish (Chanos chanos). WASJ, 33 (6), 990-995 (2015).

9. J. WU, L. KONG, J. ZHANG, W. CHEN. Extraction and properties of acid-soluble collagen and pepsinsoluble collagen from silver carp (Hypophthalmichthys molitrix) scales: prerequisite information for fishery processing waste reuse. Pol. J. Environ. Stud., 28(4), 2923-2930 (2019).

10. S. RODZIEWICZ-MOTOWIDŁO, A. ŚLADEWSKA, E MULKIEWICZ., A. KOŁODZIEJCZYK, A. ALEKSANDROWICZ, J. MISZKIEWICZ, P. STEPNOWSKI. Isolation and characterization of a thermally stable collagen preparation from the outer skin of the silver carp Hypophthalmichthys molitrix. Aquaculture, 285, 130-134 (2008).
11. J.J. ZHANG, R. DUAN, C. YE, K. KONNO. Isolation and characterization of collagens from scale of silver carp (Hypophthalmichthys molitrix). J. Food Biochem, 34, 1343-1354 (2010).

12. J. ZHANG, R. DUAN, Y. TIAN, K. KONNO. Characterisation of acid-soluble collagen from skin of silver carp (Hypophthalmichthys molitrix). Food Chem, 116, 318-322 (2009).

13. Y-S. LIM, Y-J. OK, S-Y. HWANG, J-Y. KWAK, S. YOON. Marine Collagen as A Promising Biomaterial for Biomedical Applications. Mar. Drugs., 17, doi:10.3390/md17080467 (2019).

14. https://www.eurofish.dk/romania (24 July 2020 last data accessed)

15. LI D., MU C., CAI S., LIN W. Ultrasonic irradiation in the enzymatic extraction of collagen. Ultrason Sonochem., 16(5), 605-609 (2009).

16. P. BERILLIS. Marine Collagen: Extraction and Applications. Research trends in biochemistry, molecular biology and microbiology, 1-13 (2015).

17. S. MAHBOOB. Isolation and characterization of collagen from fish waste material- skin, scales and fins of Catla catla and Cirrhinus mrigala. J Food Sci Technol, 52(7), 4296-4305 (2015).

18. P.K. BHAGWAT, P.B. DANDGE. Isolation, characterization and valorizable applications of fish scale collagen în food and agriculture industries. Biocatal. Agric. Biotechnol., 7, 234-240 (2017).

19. M. BLANCO, A.V. JOSÉ, R. PÉREZ-MARTÍN, C.G. SOTELO. Collagen extraction optimization from the skin of the small-spotted catshark ( $S$. canicula) by response surface methodology. Mar. Drugs, 17, doi:10.3390/md17010040 (2019).

20. F.A.K. ARDHANI, M. SAFITHRI, K. TARMAN, HUSNAWATI, SETYANINGSIH I., MEYDIA. Antioxidant activity of collagen from skin of parangparang fish (Chirocentrus dorab) using DPPH and CUPRAC methods. IOP Conf. Series: Earth and Environmental Science, 241, doi:10.1088/1755-1315/ 241/1/012032 (2019).

21. S. PANG, Y. P. CHANG, K.K. WOO. The evaluation of the suitability of fish wastes as a source of collagen. $2^{\text {nd }}$ International Conference on Nutrition and Food Sciences. IACSIT Press, Singapore, 53, DOI: 10.7763/ IPCBEE (2013).

22. F. YU, C. ZONG, S. JIN, J. ZHENG, N. CHEN, J. HUANG, Y. CHEN, F. HUANG, Z. YANG, Y. TANG, G. DING. Optimization of extraction conditions and characterization of pepsin-solubilised collagen from skin of giant croaker (Nibea japonica). Mar. Drugs 16, doi:10.3390/md16010029 (2018).

23. M. AHMAD, S. BENJAKUL. Extraction and characterisation of pepsinsolubilised collagen from the skin of unicorn leatherjacket (Aluterus monocerous). Food Chem, 120, 817-824 (2010). 
24. C. MING-MAO, H. YU-QIN, G. HAO, L. YAN, J-H. WANG, J-L. WU, Q-Q. ZHANG. Preparation, characterization, and potential biomedical application of composite sponges based on collagen from silver carp skin. J. Appl. Polym. Sci., DOI: 10.1002/APP. 40998 (2014).

25. A.L. ALVES, P. MARQUES, E. MARTINS, T.H. SILVA, R.L. REIS. Cosmetic potential of marine fish skin collagen. Cosmetics, 4 (4), doi:10.3390/cosmetics 4040039 (2017).

26. Y. TANG, S. JIN, X. LI, X. HU, Y. CHEN, F. HUANG, Z. YANG, F. YU, G. DING. Physicochemical properties and biocompatibility evaluation of collagen from the skin of giant croaker (Nibea japonica). Mar. Drugs, 16, doi:10.3390/md16070222 (2018).

27. N.T. CHINH, V. Q. MANH, V.Q. TRUNG, T.D. LAM, M.D. HUYNH, N.Q. TUNG, N.D. TRINH, T. HOAN. Characterization of collagen derived from tropical freshwater carp fish scale wastes and its amino acid sequence, Natural Product Communications, DOI: 10.1177/1934578X19866288 (2019).

28. P. SAUMYA, S. SHUBHAM, P. ASHIM, M. BHUBANESWAR, V. RAVINDRA, S. RAJARAM. Near UV-Visible electronic absorption originating from charged amino acids in a monomeric protein, Chem. Sci., 8, 5416-5433 (2017).

29. G.N. NA. UV spectroscopic characterization of type I collagen. Collagen Rel. Res. 8, 315 -330 (1988).
30. P. KITTIPHATTANABAWON, S. NALINANON, S. BENJAKUL, H. KISHIMURA. Characteristics of pepsin-solubilised collagen from the skin of splendid squid (Loligo formosana), J Chem., http://dx.doi.org/ 10.1155/2015/482354 (2015).

31. Y. WANG, J.M. REGENSTEIN, Effect of EDTA. $\mathrm{HCl}$, and Citric Acid on Ca Salt Removal from Asian (Silver) Carp Scales Prior to Gelatin Extraction. J. Food Sci., 74(6), 426-431 (2009).

32. F. PATI, B. ADHIKARI, S. DHARA. Isolation and characterization of fish scale collagen of higher thermal stability, Bioresource Technology, 101, 3737-3742 (2010).

33. A. SIONKOWSKA, J. KOZŁOWSKA, Fish scales as a biocomposite of collagen and calcium salts. Key Eng. Mater, 587, 185-190 (2014).

34. J. CHEN, M. LI, R. YI, K. BAI, G. WANG, R. TAN, S. SUN, N. XU. Electrodialysis extraction of pufferfish skin (Takifugu flavidus): a promising source of collagen. Mar. Drugs, 17, doi:10.3390/md17010025 (2019).

35. C. SOMAIAH, A. KUMAR, D. MAWRIE, A. SHARMA, S.D. PATIL, J. BHATTACHARYYA. Collagen promotes higher adhesion, survival and proliferation of mesenchymal stem cells. Plos One, 10(12) doi:10.1371/journal.pone.0145068Adhesion (2015). 